\title{
The Analysis of Syrian Refugee Patients Treated With the Diagnose of Hydrocephalus: The Study of 28 Cases
} Hidrosefali Tanısılla Tedavi Gören Suriyeli Mülteci Hastaların Analizi: 28 Olgunun Incelenmesi

\author{
Ömer Aykanat \\ Dr. Ersin Arslan Training and Research Hospital, Department of Neurosurgery, Gaziantep, Turkey
}

\begin{abstract}
Hydrocephalus is a condition which results from some abnormalities in normal pathology of cerebrospinal fluid in the brain (CSF) and dilatation of ventricles, occurring with sometimes increased pressure and sometimes without any pressure and it displays various clinical findings. Hydrocephalus does not contain only the pathological entity; it involves a wide pathological group as well. Therefore, though it is possible to make various classification for hydrocephalus, it can be divided into two groups as congenital and acquired in terms of etiological. The exact diagnosis of hydrocephalus is determined by screening neural tissue. These screening methods are transfontanellar ultrasound, computed tomography (CT) and magnetic resonance imaging (MRI). The main treatment for hydrocephalus is surgical. The fundamental aim in surgical treatment is to make parenchymal thickness $3.5 \mathrm{~cm}$ by reducing the intracranial pressure (ICP) to normal levels in order to increase brain tissue volume. In our research, we retrospectively studied on 28 Syrian refugees treated because of hydrocephalus for one year. We assessed the patients' age, sex, complaint, etiology, factors during the disease, shunt infection, shunt dysfunction, surgical complications and post-operative findings. We searched for the age distribution of the patients, the number of men and women and the factors seen during the disease. We classified the complaints of the patients, etiological factors and the developing complications on the patients by calculating their numbers. We assessed the improvement of the patients' complaints after surgical operation and the continuing situation for 4 months follow-up on average.
\end{abstract}

Key words: hydrocephalus; refugee; surgery

\section{ÖZET}

Hidrosefali, BOS'un normal patofizyolojisindeki bir takım bozukluklar sonucu ortaya çıkan, ventriküllerde genișleme, bazen basınç artıșı ile, bazen de basınç artıșı olmadan karșımıza çıkan ve değișik klinik bulgular veren bir durumdur. Hidrosefali tek bir patolojik antite olmayıp geniș bir patoloji grubunu içerir. Bu

Ömer Aykanat, Binevler Mah. 52. Sok. No: 39/5 Sabinbey Gaziantep, Türkiye,Tel.05072178443Email.yomeycik@hotmail.com Geliş Taribi: 07.02.2016 • Kabul Taribi: 04.03.2017 nedenle hidrosefalide çok çeșitli sınıflamalar mümkün olmakla birlikte etyolojik olarak konjenital ve edinsel olarak ikiye ayrılabilir. Hidrosefalinin kesin tanısı nöral dokunun görüntülenmesi ile konur. Bu görüntüleme yöntemleri; transfontanel ultrasonografi (USG), bilgisayarlı beyin tomografisi (BBT) ve magnetik rezonans görüntüleme (MRG)'dir. Hidrosefalinin tedavisinde asıl tedavi cerrahidir. Cerrahi tedavideki asıl amaç kafa içi basıncını (KiB) normal değerlere indirip beyin dokusu volümünü artırarak serebral parankim kalınlığını en az 3,5 cm'ye ulaștırmaktır. Biz bu yazımızda1 yıl içinde hidrosefali nedeniyle tedavi edilen 28 Suriyeli Mülteci hastanın retrospektif olarak incelemesini yaptık. Hastaların yaș, cinsiyet, șikayet, etyoloji, hastalığa eșlik eden faktörler, șant enfeksiyonu, șant disfonksiyonu, cerrahi komplikasyon ve postoperatif takip bulgularını değerlendirdik. Hastaların yaș dağılımı, kadın-erkek sayısı ve hastalığa eșlik eden faktörleri araștırdık. Hastaların șikayetleri, etyolojik faktörler ile hastalarda gelișen komplikasyonlar, sayılarını hesaplayarak sınıflandırdık. Hastalara yapılan cerrahi sonrası hastaların șikayetlerindeki düzelme, devam etme hallerini ortalama 4 aylık takiple değerlendirdik.

Anahtar kelimeler: hidrosefali; mülteci; cerrahi

\section{Introduction}

Hydrocephalus is a disorder whose physiopathology is complicated and it occurs when cerebrospinal fluid (CSF) builds up too much in ventricles and subarachnoid space ${ }^{1,2}$. Although it often results from either the abnormality in CSF oscillation or the prevention of CSF from flowing, it could also develop from too much productivity of CSF as in choroid plexus tumours ${ }^{3,4}$. In adult patients, normal pressure hydrocephalus $(\mathrm{NPH})$ is mostly seen, while in child patients, non-communicable hydrocephalus $(\mathrm{NCH})$ is seen more often ${ }^{3-5}$. In this study, retrospective assessment of 28 Syrian refugee patients operated with the diagnosis hydrocephalus in our clinic was performed. 


\section{Material and Method}

Between the dates 1 January 2014 and 31 December 2015, 28 Syrian refugee patients operated with the diagnosis hydrocephalus were retrospectively studied in neurology clinic in Dr. Ersin Arslan Training and Research Hospital. We assessed the patients'age, sex, complaint, etiology, factors during the disease, shunt infection, shunt dysfunction, surgical complications and post-operative findings. The age distribution of the patients, the number of men and women and the factors seen during the disease were searched. The complaints of the patients, etiological factors and the developing complications on the patients were classified by calculating their numbers. The improvement of the patients'complaints after surgical operation and the continuing situation for 4 months follow-up were assessed.

\section{Results}

Thirteen of 28 patients operated in our clinic were men $(46.4 \%)$ and the rest (15) were women (53.6\%). The average age of the patients whose age frequencies ranging from 2 months to 76 years is 8 months. Of the patients, $21(75 \%)$ were smaller than 1-year-old, whereas 3 (10.7\%) were mature. The age of other 4 patients changed between 1 and 12 years old (Table 1 ). It was determined that 23 of the patients $(82.1 \%)$ came to our clinic with the complaint of head circumference growth, 3 of them (\% 10.7) with walking abnormalities and urinary incontinence and 2 of them (7\%) with lack of head control, nausea and vomiting (Table 2). In the table of hydrocephalus, it was shown that the 8 of the patients have Chiari malformation (28.5\%), 2 of them $(7 \%)$ have corpus callosum dysgenesis/agenesis, 2 of them (7\%) have arachnoid cyst, 1 of them (3.5\%) has mega cisterna magna, 2 of them $(7 \%)$ have porencephalic cyst and 1 of them (3.5\%) has cerebellar hypoplasia. It was shown that 11 patients $(39.3 \%)$ have spinal dysraphism (meningocele/meningomyelocele/ lipomeningomyelocele). For 8 patients (28.5\%), there was no other companion disease with hydrocephalus (Table 3). It was determined that 16 of the patients (57\%) have congenital hydrocephalus, while 3 of them (10.7\%) have NPH. In the diagnosis of all patients computed tomography (CT) was used. Magnetic resonance screening was practised to 14 patients followed (50\%) who have intracranial pathologies such as Chiari malformation, corpus callosum dysgenesis/agenesis, arachnoid cyst, mega cisterna magna, porencephalic cyst and cerebellar hypoplasia. In the diagnosis of hydrocephalus, together with the clinic evans ratio which was calculated by being measured in CT was benefitted. It was observed that evans ratio was between $\% 40$ and 50 for 3 of the patients (10.7\%) and the ratio was higher than $50 \%$ in 25 patients (89.3\%). It was detected that 3 patients whose evans ratio changes from $\% 40-50$ were in adult age and all these 3 patients had NPH. Of our patients, 7 of them (25\%) were the ones who were operated in Syria before and re-operated because of shunt dysfunction in our clinic, whereas 21 of them were diagnosed and operated in our clinic for the first time. The average post-op duration of the patients who didn't have any intraoperative complication was 5 months (2 months-1 year). Within the length of follow-up, because of the shunt dysfunction, shunt revision was done for only 2 of the patients (7\%), while no other complication was observed in other patients (Table 4).

Table 1. The distribution of the patients according to their age and sex

\begin{tabular}{lccc}
\hline Age & Man & Woman & Total \\
\hline $0-1$ year & 11 & 10 & 21 \\
$1-12$ year & 0 & 4 & 4 \\
$>18$ year & 2 & 1 & 3 \\
\hline
\end{tabular}

Table 2. The distribution of the complaints of patients

\begin{tabular}{lc}
\hline Complaint & $\begin{array}{c}\text { Number of } \\
\text { patients }(\%)\end{array}$ \\
\hline Head circumference growth & $23(82.1)$ \\
Walking abnormalities and urinary incontinence & $3(10.7)$ \\
Lack of head control, nausea and vomiting & $2(7)$ \\
\hline
\end{tabular}

Table 3. Accompanying diseases

\begin{tabular}{lc}
\hline Disease & Number (\%) \\
\hline Spinal dysraphism & $11(39.3)$ \\
Chiari malformation & $8(28.5)$ \\
Corpus callosum dysgenesis/agenesis & $2(7)$ \\
Arachnoid cyst & $2(7)$ \\
Porencephalic cyst & $2(7)$ \\
Mega sisterna Magna & $1(3.5)$ \\
Cerebellar hypoplasia & $1(3.5)$ \\
\hline
\end{tabular}

Table 4. Complications developing after surgery

\begin{tabular}{lc}
\hline Complications & Number (\%) \\
\hline Shunt dysfunction & $2(7)$ \\
Not developing any complication & $26(93)$ \\
\hline
\end{tabular}




\section{Discussion}

Hydrocephalus is a condition which results from some abnormalities in normal pathology of cerebrospinal fluid in the brain (CSF) and dilatation of ventricles and which is encountered with sometimes increased pressure and sometimes without any pressure and which displays various clinical findings ${ }^{6}$. Hydrocephalus is not only a pathological entity; but it involves a wide pathological group as well. Therefore, though it is possible to make various classifications for hydrocephalus, it can be divided into two groups as congenital and acquired in terms of etiological ${ }^{7}$. Congenital hydrocephalus gives findings in early stage and it occurs depending on aqueduct stenosis, atresia of the foramen of Monro, Arnold-Chiari and Dandy-Walker malformations, benign intracranial cysts, infections, intraventricular haemorrhages, genetic defects and teratogens ${ }^{8}$. The most accompanying pathogen to congenital hydrocephalus is spinal dysraphism (meningocele/meningomyelocele) condition and hydrocephalus is seen in most of the patients with spinal dysraphism ${ }^{9}$. In our series, spinal dysraphism accompanied to 11 patients from 28 (39.3\%). From this aspect, our study displays suitability with the literature. Apart from spinal dysraphism, in 8 of the patients $(28.5 \%)$ Chiari malformation, in 2 of them $(7 \%)$ corpus callosum dysgenesis/agenesis, in 2 of them (7\%) arachnoid cyst, in one of them $(3.5 \%)$ mega cisterna magna, in 2 of them (7\%) porencephalic cyst and in one of them (3.5\%) cerebellar hypoplasia accompanied to hydrocephalus table. No pathology accompanying to hydrocephalus was observed in 8 patients (28.5\%). Acquired hydrocephalus are the ones resulting from tumours, intracerebral or intraventricular haemorrhages and infections.

In the diagnosis of hydrocephalus, history, complaint and physical examination are important. The presence of pathologies accompanying to hydrocephalus such as meningomyelocele, growth head according to the age, tight and fluffy fontanel and separated sutures are the warning signs for the diagnosis. However, the exact diagnosis of hydrocephalus is made with the screening of neural tissue. These screening methods are transfontanellar ultrasound, computed tomography (CT) and magnetic resonance imaging (MRI) ${ }^{10}$. Transfontanellar ultrasound is preferred particularly in prenatal period and premature infants. It has some advantages such as making bedside work-up, causing radiation, stipulating no sedation and being repeatable in required frequencies. The most crucial disadvantages are the lack of imaging quality and the lack of assessment of posterior fossa. CT is the most commonly used screening method since it scarcely stipulates sedation and its imaging quality is higher. The most important disadvantage of CT is the patient's exposure to radiation ${ }^{11}$. Therefore, CT is avoided in infants and new-borns because of long-term concerns of radiation. However, MRI shows the accompanying pathology to hydrocephalus and anatomical details with high screening quality and could image cerebrospinal fluid in the brain (CSF) dynamically ${ }^{12}$. Although it is superior than other screening methods from this point, it is difficult to use in early infancy period since it stipulates sedation and lasts longer. For all of our patients, CT was preferred as radiological imaging since the important part of the patients is within the infancy period and since it is faster, but MRI was done to study the pathology thoroughly on 14 patients (50\%) detected intracranial pathology accompanying to hydrocephalus in $\mathrm{CT}$.

Though carbonic anhydrase inhibitors and osmotic diuretics were tried to reduce CSF in the treatment of hydrocephalus, the effect of this treatment is temporary and the main treatment is surgical ${ }^{13}$. The fundamental aim in surgical treatment is to make parenchymal thickness $3.5 \mathrm{~cm}$ by reducing the intracranial pressure (ICP) to normal levels and increasing brain tissue volume. Here, the cortical thickness is regarded as one of the criteria in order to save cognitive functions of the patients ${ }^{13}$. The most used method in surgical treatment is the process to transfer CSF in ventricles to pleura, atrium or peritoneum with the help of a catheter ${ }^{14,15}$. Another surgical treatment alternative is the third ventriculostomy which is especially effective on aqueduct stenosis. However, this method is insufficient for the cases of communicating hydrocephalus ${ }^{16}$. In our series, medium pressure ventriculoperitoneal shunt was inserted in all cases and postoperative results were evaluated as highly favourable.

The most important complication of shunt application used in the treatment of hydrocephalus is the development of shunt dysfunction owing to mechanic or infective reasons. About half of shunt dysfunctions occurs within two years after shunt is inserted ${ }^{17,18}$. In this case, hydrocephalus clinic that exists on the patient before operation would re-appear. To diagnose shunt dysfunction earlier, necessary information should be given to the patient and his relatives and postoperative 
condition should be closely followed. In our series, in only 2 patients (7\%) shunt dysfunction developed and shunt revision operation was performed with early diagnosis. It was observed that in both patients, dysfunction developed due to obstruction development in the catheter and not observed any infective table.

The survival rate of the patients with hydrocephalus is around $90 \%$, although it changes depending on prognosis etiology, anomalies accompanying to the disease, developing post-op complications and early or late interventions to these complications ${ }^{19}$. However, in untreated hydrocephalus cases, about half of the patients dies in the first 3 years and an important part of them ends up with mortality before the patient reaches maturity ${ }^{17}$.

In recent years, with the increasing violence in the Middle East, especially in Syria, an intense refugee immigration started across the countries in the region. The most important one among these countries is the republic of Turkey owing to its neighbourhood with Syria. The refugees might expose to discrimination in the countries they reside and they can be deprived of the most basic human rights. Education, accommodation, food supply and medical services consist of the primary ones of these rights. Required aid has been given to the refugees either from the state or from the foundations and local people in our country. The chief one of this aid is the right of refugees to benefit from free medical services.

Gaziantep city houses many Syrian refugees as it borders with Syria and since it is one of the biggest cities in South-East Anatolia. In this study, we retrospectively searched for 28 Syrian refugee patients treated because of hydrocephalus only within a year in Dr. Ersin Arslan Training and Research hospital. We assessed the patients'ages, sexes, complaints, etiologies, factors during the disease, shunt infection, shunt dysfunction, surgical complications and post-operative findings. We searched for the age distribution of the patients, the number of men and women and the factors accompanying with the disease. We classified the complaints of the patients, etiological factors and the developing complications on the patients by calculating their numbers. We assessed the improvement of the patients'complaints after surgical operation and the continuing situation for 4 months follow-up. We wished to contribute to ease their sorrow and problems of the people who came down to refugee position in the region.

\section{References}

1. Fishman MA. Hydrocephalus. In: Eliasson SG, Prensky AL, Hardin WB, editors. Neurological pathophysiology. New York: Oxford; 1978.

2. Carey CM, Tullous MW, Walker ML. Hydrocephalus: Etiology, Pathologic Effects, Diagnosis, and Natural History. In: Cheek WR, editors. Pediatric Neurosurgery, 3th ed, Philadelphia: WB Saunders Company; 1994.

3. Greitz D. Radiologicalassessment of hydrocephalus: New theories and implications for therapy. Neurosurg Rev 2004;27(3):145-65.

4. Algin O. Role of complex hydrocephalus in unsuccessful endoscopic third ventriculostomy. Child's Nerv Syst 2010;26(1):3-4.

5. Bonetti MG, Scarabino T. Rosi R, et al. Intracranial hypertension. In: Scarabino T, Salvolini U, Jinkins JR. Emergencyneuroradiology. Springer: Berlin Heidelberg 2006;195-237.

6. Zileli M. Clinical and basic physiological concepts in hydrocephalus. Aegean J Neurol Sci 1988;1:33.

7. Mori K. Hydrocephalus- revision of its definition and classification with special referenceto "Intractable Infantile Hydrocephalus”. Childs Nerv Syst 1990;6:198.

8. Schrander-Stumpel C, Fryns JP. Congenital Hydrocephalus: nosology and guidelines for clinical approach and genetic counselling. Eur J Pediatr 1998;157:355-62.

9. Beni-Adani L, Biani N, Ben-Sirah L, et al. Theoccurrence of obstructivevs absorptive hydrocephalus in newborns and infants: relevance to treatment choices. Childs Nerv Syst 2006;22:1543-63.

10. Bell WO, Nelson LH, Block SM, et al. Prenatal diagnosis and pediatric neurosurgery. Neurosurg 1997;24:134.

11. Brunetti MA, Mahesh M, Nabaweesi R, et al. Diagnostic radiation exposure in pediatric trauma patients. $\mathrm{J}$ Trauma 2011;70:24-8.

12. Dincer A, Ozek MM. Radiologic evaluation of pediatric hydrocephalus. Childs Nerv Syst 2011;27:1543-62.

13. Bilginer B, Cataltepe O. Hydrocephalus: Classification, pathophysiology and treatment. In; Korfalı E, Zileli M. Basic Neurosurgery, 1st ed. Ankara: Tr Neurosurg Ass 2010;1899-910.

14. Wallman LJ. Shunting for hydrocephalus an oral history. Neurosurg 1982;11:308.

15. Hanigan WC, Morgan A, Shaaban A, et al. Surgical treatment and longterm neurodevelepmental outcome for infants with idiopathic aqueductal stenosis. Childs Nerv Syst 1991;7:386.

16. Cinalli G, Spennato P, Nastro A. Hydrocephalus in aqueductal stenosis. Childs Nerv Syst 2011;27:1621-42.

17. Chumas P, Tyagi A, Livingston J. Hydrocephalus -what's new? Arch Dis Child Fetal Neonatal Ed 2001;85:149-54.

18. Stein SC, Guo W. Have we made progress in preventing shunt failure? A critical analysis. J Neurosurg Pediatr 2008;1:40-7.

19. Casey AT, Kimmings EJ, Kleinlugtebeld AD. The longterm outlook for hydrocephalus in childhood. A ten-year cohort study of 155 patients. Pediatr Neurosurg 1997;27:63-70. 